\title{
Wilcoxon Analysis to Compare the Open Unemployment Rate Before and After the Implementation of ASEAN Economic Community (EAC) In Indonesia
}

\author{
Novalia $^{1}$, Nur'aeni $^{2}$, Husna Purnama ${ }^{3}$, Indriyani ${ }^{4}$ \\ 1,2,3,4 Universitas Saburai,Indonesia \\ ${ }^{1}$ Correspondence Address; novaliasholehah@gmail.com
}

\begin{abstract}
The implementation of the EAC should be seen positively since it opens the opportunities for job seekers in Indonesia to have a career abroad. With varied employment opportunities, it is expected that the open unemployment rate in Indonesia will decline. The purpose of this study is to compare the level of open unemployment rate in Indonesia before and after the implementation of the ASEAN Economic Community (EAC) using Wilcoxon Analysis. This research is quantitative. Wilcoxon analysis is used to compare the open unemployment rate in Indonesia before and after the EAC is implemented. The result shows that there is no significant difference between the average open unemployment rate before and after the implementation of EAC.
\end{abstract}

Keywords: Wilcoxon Analysis, EAC, Non-parametric Statistics, Open Unemployment Rate (OUR)

\section{INTRODUCTION}

Indonesia, with its large population, is the potential for companies to market their products and services as well as the abundant potential of the labor market. In 2013, the number of workers in Indonesia was quite large based on data from the Central Bureau of Statistics (BPS). The workforce population was 106.28 million with a full workforce of $67 \%$ of the total workforce. This shows that the number of job seekers was $33 \%$ of the workforce and the open unemployment rate in 2013 was $6.25 \%$. Indonesia is one of the ten ASEAN member countries. The leaders of ASEAN at the 1997 Summit in Kuala Lumpur, followed by a summit in Bali in 2003, agreed to establish the ASEAN Economic Community (EAC). EAC began to be implemented in 2015. This means that in 2015, the formation of a single market and unitybased production was supported by the free commodity flow, services, investment, capitals, and skilled labors.

The free flow of skilled labors can mean that all citizens of ASEAN countries can go in and out to find work without any obstacles from the intended country. Skilled workers are workers who have expertise, special skills, knowledge, and expertise in their fields that can come from college graduates or those supported by informal skills obtained from informal educational institutions such as foreign language courses or other competency courses as well as from work experience (Evienia, Aldi, \& Madhayaratri, 2014). One of the preparations of the Indonesian government in dealing with the MEA is to improve the quality of human resources through the master plan for the Acceleration and Expansion of Indonesian Economic Development (MP3EI) 2011-2025. The implementation of MEA should be seen as a positive thing since it opens the opportunities for job seekers in Indonesia to have a career abroad. Also, the level of open unemployment rate in Indonesia before and after the implementation of the EAC needs to be compared. Comparative analysis can use parametric statistics and nonparametric statistics. If the assumptions in parametric statistics are not met, the non-parametric statistics can be used. Wilcoxon analysis is a non-parametric statistical analysis used to compare 
two groups of correlated data. This analysis will be used to compare the level of open unemployment rate in Indonesia before and after the implementation of EAC.

Based on previous research, several studies have been carried out on issues related to the unemployment rate in Indonesia (Amalia, 2012; Andhykha, Handayani, \& Woyanti, 2018; Bintang \& Woyanti, 2018; Darma Rika Swaramarinda \& Puruwita, 2012; Darman, 2013; Dian Purnama Yanti Cok Istri, 2015; Nurulita, Arifulsyah, \& Yefni, 2018; Sari, Anwar, \& Darussamin, 2016; Septiatin, Mawardi, \& Rizki, 2016) and several studies on Wilcoxon Analysis (Ayadi \& Ghorbel, 2018; Fang, Du, \& Cui, 2012). However, no previous research has used the Wilcoxon Analysis to compare the level of open unemployment rate in Indonesia.

Based on the previous research, the renewal in this study lies in the use of the Wilcoxon Analysis to compare the level of open unemployment rate in Indonesia before and after the implementation of the ASEAN Economic Community (EAC). So, the purpose of this study is to compare the level of open unemployment rate in Indonesia before and after the implementation of the ASEAN Economic Community (EAC) using the Wilcoxon Analysis

\section{THE RESEARCH METHODS}

This research is a quantitative study. The data used was the open unemployment rate data from 33 provinces in Indonesia before the implementation of EAC (2013-2014) and after the implementation of EAC (2015-2016). The primary data was obtained by researchers from the BPS website. The comparison analysis used is the Wilcoxon Analysis with the help of statistics software.

\section{THE RESULTS OF THE RESEARCH AND THE DISCUSSION}

Data on the open unemployment rate from 33 provinces in Indonesia is calculated twice per year, namely in February and August. The open unemployment rate used in this research were two groups of data, namely open unemployment rate data before the implementation of the EAC (2013-2014) and after the implementation of EAC (2015-2016). The description can be seen in Table 1.

Table 1. The Open Unemployment Rate Data Before and After the implementation of EAC

\begin{tabular}{ccccccc}
\hline Open Unemployment Rate Data & $\mathbf{N}$ & $\mathbf{m i n}$ & $\mathbf{m a x}$ & mean & $\mathbf{S}$ & $\mathbf{S}^{\mathbf{2}}$ \\
\hline Before EAC & 132 & 1,37 & 10,51 & 5,091 & 2,271 & 5,161 \\
After EAC & 132 & 1,37 & 9,93 & 5,293 & 2,025 & 4,101 \\
\hline
\end{tabular}

Based on table 1, it can be seen that the open unemployment rate values are not much different, even almost the same. The minimum value of the open unemployment rate before and after the implementation of AEC is the same which is 1.37. The minimum unemployment rate is in Bali province while the maximum unemployment rate before the implementation of EAC is 10.51 in Maluku province and the maximum unemployment rate after the implementation of AEC is 9.93 in the Aceh province. The mean, standard deviation, and diversity of data on open unemployment rate before and after the implementation of AEC is not much different. The description of open unemployment rate data before and after the implementation of AEC can be seen in Figure 1. 


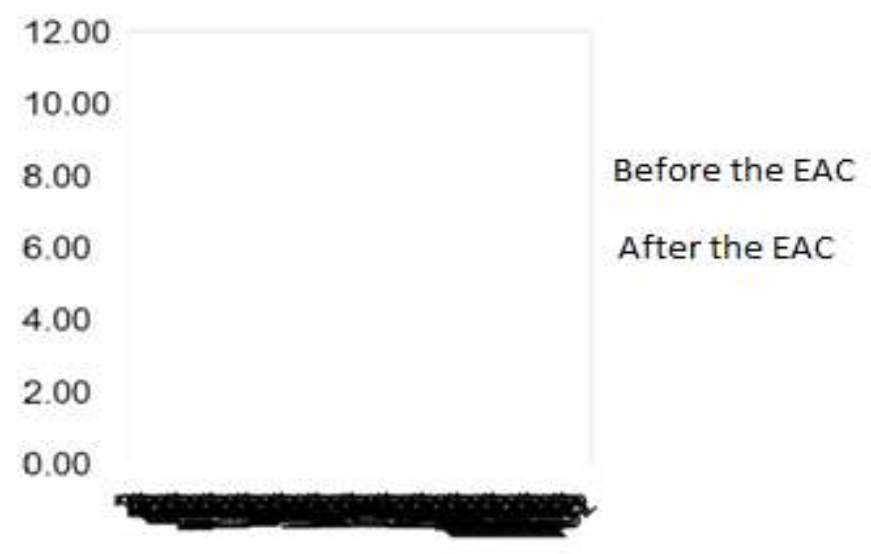

Figure 1. The Open Unemployment Rate Diagram in Indonesia before and after the Implementation of AEC

Based on Figure 1 it can be seen that the open unemployment rate before and after the implementation of AEC in 33 provinces in Indonesia is not much different. There is a high open unemployment rate before the implementation of the AEC yet there is also a high open unemployment rate after the implementation of MEA. Wilcoxon analysis is used to compare the level of open unemployment in Indonesia before and after the implementation of EAC. The results of the Wilcoxon analysis with the help of statistics software can be seen in Table 2 .

Table 2. The Result of Wilcoxon Analysis

Test Statistics $^{\mathrm{b}}$

\begin{tabular}{|l|r|}
\hline & $\begin{array}{l}\text { OUR_After_EAC - } \\
\text { OUR_Before_EAC }\end{array}$ \\
\hline$Z$ & $-1.647^{\mathrm{a}}$ \\
Asymp. Sig. (2-tailed) & .100 \\
\hline
\end{tabular}

a. Based on negative ranks.

b. Wilcoxon Signed Ranks Test

Based on table 2, it can be seen that the significant value of Wilcoxon test is 0.100 . This value is greater than the alpha value of 0.05 . This shows that there is no significant difference between the open unemployment rate data before and after the implementation of AEC. The implementation of the EAC does not have a significant effect on the level of open unemployment rate in 33 provinces in Indonesia. The implementation of the EAC does not make the average open unemployment rate in Indonesia increase or decrease.

MEA began to be implemented in 2015. In 2015, the formation of a single market and unity-based production was supported by the free commodity flow, services, investment, capital, and skilled labor. Those factors make the employment opportunities even greater and competition increases. There are eight professions that will be affected by free market policies contained in the ASEAN Mutual Recognition Arrangement (MRA), namely engineers, architects, tourism personnel, accountants, survey workers, medical practitioners, and nurses. Each MRA profession has set standards and competencies needed in the ASEAN arena. 
Indonesia will accept workers from ASEAN for these professions and vice versa. The government has tried to improve the quality of human resources so that Indonesian workers can compete with workers from other ASEAN countries but based on the results of the analysis it can be concluded that there is no significant difference between the open unemployment rate before and after the implementation of AEC

This shows that Indonesia is not ready to face the EAC. The number of Indonesian workers in 2013, 2014, 2015 and 2016 were 7,240,897, 7,147,069, 7,454,767 and 7,024,172 respectively. The number of Indonesian workers is high but many are low educated. Based on the level of education, the highest Indonesian workforce before and after the implementation of EAC are workers who have a proper education, which is equal to $26.23 \%$ while Indonesian workers who are highly educated (University graduates) are only $7.31 \%$. The following are data on the average percentage of Indonesian labor force (2013-2016) based on the level of education presented in Table 3.

Table 3. Average Percentage of Indonesian Workers (2013-2016)

\begin{tabular}{clc}
\multicolumn{3}{c}{ Based on Education } \\
\hline No & Level of Education Level & Percentage \\
\hline 1 & Senior High School Level & 26.23 \\
2 & Junior High School Level & 21.41 \\
3 & Elementary School & 17.18 \\
4 & Vocational High School / & 17.12 \\
& Vocational School & \\
5 & University (have not graduated & 7.31 \\
& or drop-out) & 6.78 \\
6 & Elementary school & 3.01 \\
7 & Academy / Diploma & 1.27 \\
8 & Have never attended school &
\end{tabular}

Based on Table 3, we can conclude that the programs done by the Indonesian government in improving human resources through education has not been successful. Many Indonesian workers are low-educated, whereas in facing the EAC, a skilled and highly educated workforce is needed. Companies need highly educated professionals because the position of jobs with low education such as labor has been replaced by mechanical power.

The low level of education of the Indonesian people causes high OUR in Indonesia, so that the average OUR before and after the EAC has no significant difference. The Open Unemployment Rate (OUR) is the percentage of unemployed people to the number of open unemployment labor force, consisting of:

a. Those who don't have jobs and are looking for work

Finding a job is an activity of a person who at the time of the survey is looking for a job, such as someone who has never worked and is trying to get a job, someone who has worked but for some reason stops or is stopped and is trying to get a job, people who work or have work but for some reason still trying to get another job. The efforts in finding the job are not limited to a week before the survey so those who are trying to get a job and whose letter of application 
has been sent more than a week are still considered as looking for a job. Those who are working and trying to get another job cannot be called open unemployed.

b. Those who don't have jobs and is preparing their own businesses

Preparing for a business is an activity carried out by a person in order to prepare a "new" business/job which aims to obtain income/profit at his own risk, both with and without paying/not paying the workers. Preparing means "the action is real", such as: collecting capital or equipment/tools, looking for a location/place, arranging a business permit and so on. Preparing a business does not include those who are just planning, intending, and just taking a course/training in order to open a business.

c. Those who do not have a job and are not looking for work because they feel it is impossible to get a job.

d. Those who already have jobs but have not started working.

The OUR formula is as follows:

$$
\text { OUR }=\frac{\text { The Number of Unemployement }}{\text { The Number of } \text { Workforce }} \times 100 \%
$$

The working age population is a population aged 15 years and over. The workforce population are the working age population (15 years and over) who work or have a job but temporarily unemployed.

The establishment of the ASEAN Economic Community (EAC) began with the agreement of leaders of ASEAN at the Summit on December 1997 in Kuala Lumpur, Malaysia and the Bali Summit on October 2003 in Indonesia by declaring the formation of the EAC in 2015. One point of agreement was the formation of a single market and unity of production supported by free commodity flow, skilled labor, services, investment, and capital. The ASEAN economic community is expected to become a single market and production base where the commodity flow, services, investment, capital, and skilled workers can be free to move. The definition of a shared free market is the creation of conditions for full free trade and capital and free-moving workers. This indicates that all countries in the Southeast Asian region have the same rights and obligations to move freely in the ASEAN region. Freedom of movement for workers means that they have the right to live and find work throughout the ASEAN region.

The main purposes of the establishment of the ASEAN Economic Community (EAC) are:

1. Creating a single market that includes ASEAN countries as well as the center of production (production base) related to the elements of free economic activities products, such as labor (educated/skilled), custom free commodity flow and services from the ASEAN region as well as the influx of investment and capital flows for countries in the region.

2. Making ASEAN an area of high economic competitiveness marked by strengthening the regulations in economic competition, including consumer protection, Intellectual Property Rights (IPR), taxation, good Commerce activities, and infrastructure development.

3. Leveling the economic empowerment of the ASEAN region with the main goal of revitalizing small and medium enterprises (SMEs), especially for the Cambodia, Myanmar, Laos, and Vietnam (CMLV) since the CMLV has long and repeatedly been wracked by a variety of political, social, and cultural problems that affect the country's security. Thus, as 
summarized in the ASEAN Vision 2020 and the ASEAN Concord II Pact, the EAC is established with the intention to equalize the economy throughout the region.

4. Integrating regional economies with the global economy is the basic goal of increasing ASEAN's participation in global policy arena. This is done by a coherent approach between regional and global economy. This is one positive side because later, the input of ASEAN countries can be considered important.

The implementation of EAC should increase the number of Indonesian workers or reduce the open unemployment rate in Indonesia. The government must make the right concepts, strategies, and policies so that human resource development in Indonesia can achieve the right targets effectively and efficiently. This is important because improving the quality of Indonesian human resources is not only to increase productivity and competitiveness both nationally and internationally but also to improve the welfare and equal distribution of income for the people of Indonesia. So that one of the goals of the EAC in economic equality within the scope of the countries incorporated in ASEAN is achieved.

\section{CONCLUSION AND SUGGESTION}

Based on the results of the data analysis, it can be concluded that there is no significant difference between the average open unemployment rate before and after the implementation of EAC. The suggestions related to the results and findings in this study are for further research in order to conduct research with a wider context which certainly can be useful information for the advancement of Indonesia.

\section{REFERENCES}

Amalia, F. (2012). Pengaruh Pendidikan, Pengangguran Dan Inflasi Terhadap Tingkat Kemiskinan Di Kawasan Timur Indonesia (Kti) Periode 2001-2010. Econosains: Jurnal Online Ekonomi Dan Pendidikan, 10(2), 158-169.

Andhykha, R., Handayani, H. R., \& Woyanti, N. (2018). Analisis Pengaruh Pdrb, Tingkat Pengangguran, Dan Ipm Terhadap Tingkat Kemiskinan Di Provinsi Jawa Tengah. Media Ekonomi Dan Manajemen., 33(2).

Ayadi, S., \& Ghorbel, S. Z. (2018). Relevance Of The Mann Whitney Wilcoxon Test In The Survival Analysis Of Newly Established Companies In Tunisia (Case Of The Sfax Region). Journal Of Global Entrepreneurship Research, 8(1), 1-20.

Bintang, A. B. M., \& Woyanti, N. (2018). Pengaruh Pdrb, Pendidikan, Kesehatan, Dan Pengangguran Terhadap Tingkat Kemiskinan Di Jawa Tengah (2011-2015). Media Ekonomi Dan Manajemen, 33(1).

Darma Rika Swaramarinda, M., \& Puruwita, D. (2012). Pengaruh Tingkat Pendidikan, Pendapatan Per Kapita Dan Pengangguran Terhadap Kemiskinan Di Dki Jakarta. Econosains: Jurnal Online Ekonomi Dan Pendidikan, 10(2), 144-157.

Darman. (2013). Pengaruh Pertumbuhan Ekonomi Terhadap Tingkat Pengangguran: Analisis 
Hukum Okun. Journal The Winners: Economics, Business, Management, And Information System Journal, 14(1), 1-12.

Dian Purnama Yanti Cok Istri, M. A. A. I. N. (2015). Pengaruh Pendidikan, Tingkat Upah Dan Pengangguran Terhadap Persentase Penduduk Miskin Di Kabupaten/Kota Provinsi Bali. Piramida, 11(2).

Evienia, Aldi, \& Madhayaratri. (2014). Pandangan Pelaku Pendidikan Di Universitas terhadap Pemberlakuan Masyarakat Ekonomi ASEAN 2015. Jurnal Bina Ekonomi Fakultas Ekonomi Unpar, 18(2), 85-97.

Fang, Z., Du, R., \& Cui, X. (2012). Uniform Approximation Is More Appropriate For Wilcoxon Rank-Sum Test In Gene Set Analysis. Plos One, 7(2).

Nurulita, S., Arifulsyah, H., \& Yefni. (2018). Analisis Pengaruh Kinerja Keuangan Daerah Terhadap Pertumbuhan Ekonomi Dan Dampaknya Terhadap Tingkat Pengangguran Di Provinsi Riau. Jurnal Benefita, 3(3), 336-356.

Sari, S. P., Anwar, D. D., \& Darussamin. (2016). Analisis Pdrb, Tingkat Pendidikan Dan Tingkat Pengangguran Terhadap Tingkat Kemiskinan Di Provinsi Sumatera Selatan Periode 2004-2013. I-Economics: A Research Journal On Islamic Economics., 2(1), 86101.

Septiatin, A. A., Mawardi, M. M., \& Rizki, M. A. K. (2016). Pengaruh Inflasi Dan Tingkat Pengangguran Terhadap Pertumbuhan Ekonomi Di Indonesia. I-Economics: A Research Journal On Islamic Economics., 2(1), 50-65. 